\title{
Changes in the profile of speech-language therapists from Paraná and Santa Catarina from 2000 to 2011
}

\section{Modificações no perfil dos fonoaudiólogos atuantes no Paraná e em Santa Catarina nos anos 2000 e 2011}

\author{
Ana Paula Berberian', Angela Ribas², Giselle Massi', Jair Mendes Marques', Maria Regina Franke Serratto', \\ Ana Cristina Guarinello
}

\begin{abstract}
Purpose: Comparative analysis of the profile of speech-language therapists that work in the states of Paraná and Santa Catarina in 2000 and 2011. Methods: application of a questionnaire that considered the following variables: identification of data, undergraduates and graduates, professional aspects. The responses obtained in 2000 and 2011 were compared by means of the difference of proportions test, with a significance level of 5\%. Results: The comparison of the data has shown that: the number of speech-language therapists in the jurisdiction of the Board tripled; the profile was unchanged with regard to gender; however, there was a 10-year increase in average and maximum age; the majority of respondents in 2000 and in 2011 completed the undergraduate course in the jurisdiction of the Board; a larger migration of professionals from the capitals to other cities in the two states; significant increase of graduates in specialization courses; significant differences in employment and the type of institution in which they work; a decrease in the number of freelance professionals and an increase in the number of speech-language therapists that work in public institutions. Conclusion: There were changes in the profile of speech-language therapists that work in the states of Paraná and Santa Catarina from 2000 to 2011, especially in terms of specialization levels and actions primarily developed inside private institutions that work with clinical and rehabilitative actions for public health, and educational institutions that work with prevention and promotion.
\end{abstract}

Keywords: Speech, language and hearing sciences; Professional training; Job market; Education, Continuing

\section{RESUMO}

Objetivo: Realizar análise comparativa do perfil dos fonoaudiólogos atuantes nos Estados de Santa Catarina e Paraná nos anos de 2000 e 2011. Métodos: Aplicação de questionário, considerando as seguintes variáveis: dados de identificação; formação em graduação e pós-graduação; aspectos profissionais. As respostas obtidas em 2000 e 2011 foram comparadas entre si por meio do teste de diferença de proporções, com nível de significância de 5\%. Resultados: A comparação dos dados permitiu verificar que o número de fonoaudiólogos ativos na jurisdição do Conselho Regional que abarca os Estados do Paraná e de Santa Catarina triplicou; o perfil manteve-se inalterado quanto ao gênero, porém houve aumento de 10 anos na média de idade e na idade máxima dos profissionais atuantes nesses Estados; a maioria dos respondentes, em 2000 e 2011, concluiu o curso de graduação na jurisdição do Conselho, sendo que o maior deslocamento dos profissionais se deu da capital para cidades interioranas dos próprios Estados; houve aumento significativo de concluintes em cursos de especialização; verificou-se diminuição de profissionais autônomos e aumento do número de fonoaudiólogos empregados em instituições públicas. Conclusão: Nos anos de 2000 e 2011, houve mudanças no perfil dos fonoaudiólogos atuantes nos Estados do Paraná e Santa Catarina, especialmente, quanto à formação em nível de especialização e ao deslocamento de ações, prioritariamente desenvolvidas em instituições privadas, de caráter clínico-reabilitativo, para ações em instituições públicas de saúde e educação, voltadas à prevenção e promoção.

Descritores: Fonoaudiologia; Capacitação profissional; Mercado de trabalho; Educação continuada

\footnotetext{
Work done at Universidade Tuiuti do Paraná - UTP - Tuiuti (PR), Brazil, in partnership with the Regional Board of Speech-Language Pathology - $3^{\text {rd }}$ Region. (1) Graduate Program in Communication Disorders, Universidade Tuiuti do Paraná - UTP - Tuiuti (PR), Brazil.

Conflicts of interest: No

Authors' contribution: $A P B$, lead researcher, doing research, preparing the schedule, survey of literature, collection and analysis of data, drafting the article, article submission and procedures; $A R$, lead researcher, doing research, preparing the schedule, survey of literature, collection and analysis of data, drafting the article, article submission and procedures; $G M$, doing research, data analysis, correcting the wording of article, approval of the final version; $J M M$, statistical analysis, correcting the wording of article, approval of the final version; MRFS, doing research, data analysis, correcting the wording of article, approval of the final version; $A C G$, development of research, data analysis, correcting the wording of article, approval of the final version.
}

Correspondence address: Ana Paula Berberian. R. Alfredo Muraro, 7, Curitiba, Paraná, Brazil, CEP: 82020-132. E-mail: asilva@utp.br

Received on: 6/9/2014; Accepted on: 11/5/2014 


\section{INTRODUCTION}

In Brazil, since the 1980s, there has been greater integration of speech-language therapists in health, educational and business institutions, demanding changes in continuing education for these professionals.

Although such changes are nationwide, they do not happen directly and evenly. They involve regional differences that determine the various profiles Brazilian speech-language therapists should have $\mathrm{e}^{(1,2)}$.

Studies on the insertion of the speech-language therapists in various regions of Brazil and their different areas of expertise allow us to construct a historical overview of the profession and provide elements for the assessment of their social roles ${ }^{(3-7)}$.

This study aims to conduct a comparative analysis of the profile for speech-language therapists working in the states of Santa Catarina and Paraná in 2000 and 2011.

\section{METHODS}

Research was conducted by a technical-scientific partnership between CREFONO 3 and researchers at Universidade Tuiuti do Paraná (UTP), after approval by the Research Ethics Committee (opinion 00096/08). The need for signed consent forms was waived by the committee because the CREFONO 3 database, which does not identify respondents, was used.

This is a descriptive-analytic study and retrospective in nature. For the selection of research subjects, three inclusion criteria were simultaneously adopted: having an active registration in the jurisdiction of CREFONO 3 in 2000 and/ or 2011; working in Paraná and/ or Santa Catarina; having responded to the professional registration questionnaire prepared by the Board in 2000 and 2011.

In 2000, a total of 1485 speech-language therapists enrolled in CREFONO 3, 846 (56\%) responded to the questionnaire sent by mail. In 2011, of the 3825 enrolled, 3021 (78\%) responded to the questionnaire sent via the internet (email). Therefore this study included a total of 3867 respondents.

The questionnaire contained data regarding: identification (age and gender); education (educational institution and year of graduation); postgraduate training (specialization, Master's, doctoral, year completed, institution and graduate program); job status (area and place of work, employment, type of company, adherence to health plans, income).

Data were tabulated and treated statistically using the Sphinx software. A comparison of the profile of respondents was considered using the Difference of Proportions test and a result lower than $5 \%(\mathrm{p}<0.05)$ was considered statistically significant.

\section{RESULTS}

In $2000,97 \%(n=817)$ of respondents were female and $3 \%$ $(\mathrm{n}=29)$ were male; in $2011,96 \%(\mathrm{n}=2904)$ were female and $4 \%(\mathrm{n}=117)$ were male.

As to age, in 2000, the average age of the subjects was 27, with a minimum of 21 and maximum of 57. In 2011, the average age increased to 36 , with the minimum remaining at 21 and the maximum increasing to 66 .

The number of speech-language therapists working in the cities of Paraná and Santa Catarina offering undergraduate degrees in speech-language pathology in 2000 and 2011, is described in Table 1.

In $2000,59.70 \%$ of respondents had completed a speech-language pathology course in a Higher Education Institution (HEI) located in Parana and 16.89\% in Santa Catarina. In 2011, $58.70 \%$ had completed such training in the state of Paraná and $20.48 \%$ in Santa Catarina, as shown in Table 2.

The post-graduate education level of the respondents and a comparison of results obtained in the two periods are specified in Table 3.

Results related to the working conditions of respondents are shown in Table 4.

Data concerning the adherence of the respondents to health plans and their personal income are presented in Table 5.

\section{DISCUSSION}

The profile of respondents in terms of gender remained virtually unchanged from 2000 to 2011. As in other regions of Brazil, and other countries, speech-language therapists, in these states, are composed predominantly of women ${ }^{(1,8)}$.

As to the age of respondents, the increase in average age and maximum age by approximately 10 years follows the trend indicated by the World Bank report ${ }^{(9)}$.

The number of active speech-language therapists in Parana and Santa Catarina from 2000 to 2011 nearly tripled. Although in 2000 and 2011 there was a concentration of speech-language therapists in the capitals of these states, we observed that in 2011 there was a trend in their migration to more rural cities.

This shift highlights a regional expansion of the labor market, which may result in greater access of the population to speech therapy services in locations close to their homes In addition, these health professionals are becoming more attuned with regional specificities and the living conditions of the population ${ }^{(3)}$.

It is understood that bringing speech-language therapists closer to these diverse realities assumes that their initial and ongoing training must consider the guidelines contained in public health and education policies while providing support for the systematization of speech-language actions that consider the social determinants involved in professional activity ${ }^{(6,7,10,11)}$.

Regarding the academic background of the respondents and their institution of origin, it was found that in 2000 and 2011, the majority of respondents had completed an undergraduate degree in speech-language pathology within the Board's jurisdiction. 
Table 1. Comparative distribution of respondents in Paraná and Santa Catarina, by city

\begin{tabular}{|c|c|c|c|c|c|}
\hline \multirow{2}{*}{ City } & \multicolumn{2}{|c|}{2000} & \multicolumn{2}{|c|}{2011} & \multirow{2}{*}{$p$-value } \\
\hline & $\mathrm{n}$ & $\%$ & $\mathrm{n}$ & $\%$ & \\
\hline \multicolumn{6}{|l|}{ Paraná } \\
\hline Curitiba** & 427 & $(50.07)$ & 989 & $(32.24)$ & $0.0000^{*}$ \\
\hline Maringá ${ }^{\star \star \star}$ & 15 & $(1.77)$ & 155 & $(5.13)$ & $0.0000^{*}$ \\
\hline Londrina $^{\star *}$ & 32 & (3.78) & 151 & (4.99) & 0.1427 \\
\hline Cascavel $^{\star *}$ & 12 & $(1.41)$ & 42 & (1.39) & 0.9650 \\
\hline Irati $^{\star *}$ & 2 & $(0.23)$ & 26 & $(0.86$ & 0.0558 \\
\hline Guarapuava & 2 & $(0.23)$ & 21 & (0.69) & $0.0155^{\star}$ \\
\hline \multicolumn{6}{|l|}{ Santa Catarina } \\
\hline Florianópolis ${ }^{\star *}$ & 67 & $(7.91)$ & 224 & $(7.41)$ & 0.6260 \\
\hline Criciúma & 2 & $(0.23)$ & 27 & $(0.91)$ & $0.0044^{*}$ \\
\hline $\begin{array}{l}\text { Cities with fewer than } 10 \text { registered } \\
\text { professionals }\end{array}$ & 157 & $(18)$ & 1049 & $(34.72)$ & $0.0000^{*}$ \\
\hline Total & 846 & $(100)$ & 3021 & $(100)$ & \\
\hline
\end{tabular}

* Significant values $(p \leq 0 ., 05)-$ Difference of proportions test

** Cities that offered a course in Speech-Language Pathology in 2011

${ }^{* * *}$ Cities that offered 3 courses in Speech-Language Pathology in 2011

Table 2. Comparative distribution of respondents in relation to the education institution alma mater in Speech-Language Pathology

\begin{tabular}{|c|c|c|c|c|c|}
\hline & \multicolumn{2}{|c|}{2000} & \multicolumn{2}{|c|}{2011} & \multirow{2}{*}{$p$-value } \\
\hline & $\mathrm{n}$ & $\%$ & $\mathrm{n}$ & $\%$ & \\
\hline \multicolumn{6}{|l|}{ Paraná } \\
\hline UTP & 150 & $(12.61)$ & 662 & (21.9) & $0.0000^{*}$ \\
\hline $\mathrm{PUC/Pr}$ & 202 & $(17.06)$ & 632 & (20.9) & $0.0137^{*}$ \\
\hline UNOPAR & 96 & $(8.11)$ & 347 & $(11.48)$ & $0.0052^{*}$ \\
\hline CESUMAR & -- & $(00)$ & 105 & (3.47) & $0.0000^{*}$ \\
\hline UNICENTRO & -- & $(00)$ & 16 & $(0.52)$ & $0.0356^{*}$ \\
\hline UNINGÁ & -- & $(00)$ & 11 & $(0.36)$ & 0.0806 \\
\hline \multicolumn{6}{|l|}{ Santa Catarina } \\
\hline UNIVALI & 200 & (16.89) & 592 & (19.59) & 0.0769 \\
\hline UNESA & -- & $(00)$ & 27 & $(0.89)$ & $0.0059^{*}$ \\
\hline Other institutions Outside the jurisdiction & 198 & $(23.41)$ & 629 & (20.82) & 0.1045 \\
\hline Total & 846 & $(100)$ & 3021 & $(100)$ & \\
\hline
\end{tabular}

* Significant values $(\mathrm{p} \leq 0.05)-$ Difference of proportions test

Table 3. Comparative distribution of respondents regarding their level of post-graduate education

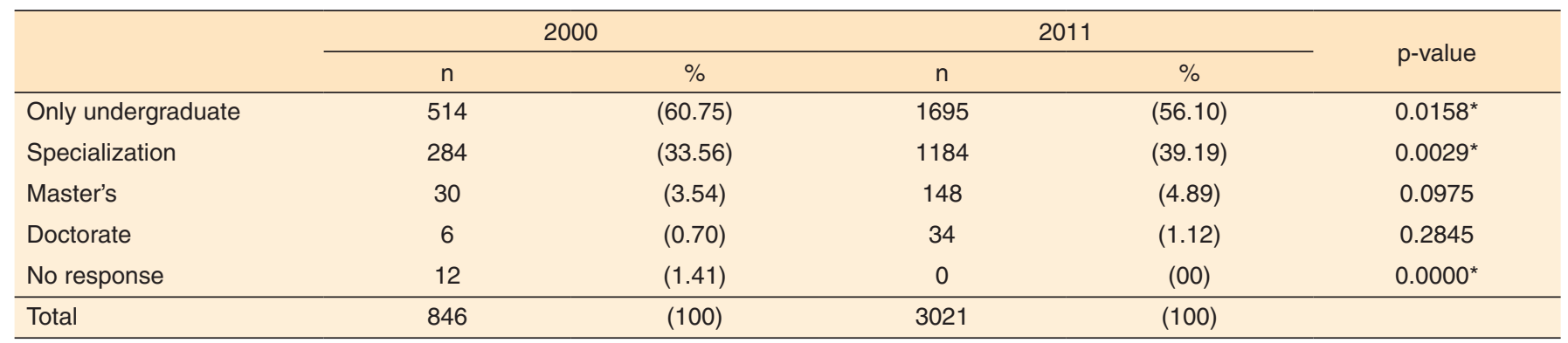

* Significant values $(p \leq 0.05)$ - Difference of proportions test 
Table 4. Comparative distribution of respondents regarding their employment status, type of institution and location of work

\begin{tabular}{|c|c|c|c|c|c|}
\hline & \multicolumn{2}{|c|}{2000} & \multicolumn{2}{|c|}{2011} & \multirow{2}{*}{$\mathrm{p}$-value } \\
\hline & $\mathrm{n}$ & $\%$ & $\mathrm{n}$ & $\%$ & \\
\hline \multicolumn{6}{|l|}{ Employment status } \\
\hline Self-employed & 470 & $(55.54)$ & 796 & $(26.34)$ & $0.0000^{*}$ \\
\hline Employee & 268 & $(31.67)$ & 1542 & $(51.04)$ & $0.0000^{*}$ \\
\hline No response & 108 & $(12.76)$ & 683 & $(22.60)$ & $0.0000^{*}$ \\
\hline Total & 846 & $(100)$ & 3021 & $(100)$ & -- \\
\hline \multicolumn{6}{|l|}{ Type of institution } \\
\hline Public & 174 & $(20.56)$ & 1838 & $(60.84)$ & $0.0000^{*}$ \\
\hline Private & 364 & $(43.02)$ & 526 & $(17.41)$ & $0.0000^{*}$ \\
\hline Philanthropic & 82 & $(9.69)$ & 34 & $(1.12)$ & $0.0000^{*}$ \\
\hline No response & 226 & $(26.71)$ & 623 & $(20.06)$ & $0.0000^{*}$ \\
\hline Total & 846 & $(100)$ & 3021 & $(100)$ & -- \\
\hline \multicolumn{6}{|l|}{ Location of work } \\
\hline Medical office & 441 & $(52.12)$ & 1006 & $(33.30)$ & $0.0000^{*}$ \\
\hline Regular school & 22 & $(2.60)$ & 178 & $(5.89)$ & $0.0001^{*}$ \\
\hline Special school & 98 & $(11.58)$ & 124 & $(4.10)$ & $0.0000^{*}$ \\
\hline City/State & 68 & (8.03) & 259 & $(8.57)$ & 0.6178 \\
\hline Teaching & 29 & $(3.42)$ & 45 & $(1.48)$ & $0.0003^{*}$ \\
\hline Hospital & 11 & $(1.30)$ & 67 & $(2.21)$ & 0.0957 \\
\hline Industry/Corporate & 12 & $(1.41)$ & 77 & $(2.54)$ & 0.0523 \\
\hline Other & 115 & $(13.50)$ & 322 & (10.65) & $0.0458^{*}$ \\
\hline No response & 50 & $(5.91)$ & 943 & $(31.21)$ & $0.0000^{*}$ \\
\hline Total & 846 & $(100)$ & 3021 & $(100 \%)$ & -- \\
\hline
\end{tabular}

* Significant values $(p \leq 0.05)-$ Difference of proportions test

Table 5. Comparative distribution of respondents regarding their adherence to health plans and personal income

\begin{tabular}{|c|c|c|c|c|c|}
\hline & \multirow{2}{*}{$\frac{2000}{n}$} & \multicolumn{3}{|c|}{2011} & \multirow{2}{*}{$\mathrm{p}$-value } \\
\hline & & $\%$ & $\mathrm{n}$ & $\%$ & \\
\hline \multicolumn{6}{|l|}{ Adherence to health plans } \\
\hline Do not receive patients from health plans & 465 & $(54.96)$ & 2091 & $(69.21)$ & $0.0000^{*}$ \\
\hline No response & 39 & $(4.60)$ & 145 & $(4.79)$ & 0.8184 \\
\hline \multicolumn{6}{|l|}{ Personal income ${ }^{\star *}$} \\
\hline $1-10 x$ minimum wage & 538 & $(63.59)$ & 1264 & $(41.84)$ & $0.0000^{*}$ \\
\hline $11-20 x$ minimum wage & 103 & $(12.17)$ & 967 & (32.01) & $0.0000^{*}$ \\
\hline More than $20 x$ minimum wage & 24 & $(2.83)$ & 434 & $(14.36)$ & $0.0000^{*}$ \\
\hline No response & 181 & $(21.39)$ & 356 & $(11.78)$ & $0.0000^{*}$ \\
\hline
\end{tabular}

* Significant values $(\mathrm{p} \leq 0.05)$ - Difference of proportions test

** In 2000 the minimum wage was $\mathrm{R} \$ 136.00 /$ month and in 2011 it was $\mathrm{R} \$ 545.00 /$ month

Regarding the level of overall training in 2000 and 2011, there was a significant decrease in respondents who held only an undergraduate degree and an increase of those who had completed specialization training.

Specialization training, which in both 2000 and 2011 included the largest number of respondents, has been seen as the type of training most interesting to Brazilian speech-language therapists because it aims to enhance and differentiate professional performance, making it a easier to compete in the labor market ${ }^{(2,10)}$.

Regarding the number of respondents who had completed post-graduate courses, there was no significant increase, a fact that agrees with some national studies ${ }^{(3,10)}$, but differs from others ${ }^{(1)}$. 
In this context, it is noteworthy that, in the states of Paraná and Santa Catarina, only UTP has ongoing post-graduate studies in the area, with Master's and doctoral programs recognized in 1998 and 2007, respectively.

With respect to the respondents' job status, data obtained in 2000 and 2011 show significant differences in the type of employment and the type of institution in which the respondents worked. There was a decrease of active independent professionals with private practices or in private companies, and an increase of those considered to be employees as well as those working in public institutions.

Upon analysis, considerations should be made about job status that characterize the performance of health professionals in general $^{(11)}$ and specifically for speech-language therapists in private practice. The latter are professionals who work in private clinics owned by others, receiving fees based on percentages paid by customers to clinic owners (less taxes for services rendered). Via the public system, health professionals receive amounts lower than those indicated by the representative governing bodies. Furthermore, seasonal fluctuations in visits and consultations contribute to the instability of income for health professionals.

The migration of speech-language therapists from the private sector to the public sector, as seen with other health professionals $^{(11)}$, is related especially to job stability, which is a characteristic of official public employment.

The rise of the number of respondents employed in public institutions, as observed in the present study, follows the expansion of speech-language therapists working in the national healthcare system ${ }^{(4,7)}$, observed since 1990 due to: the creation of the Brazilian Society of Speech Committee of Public Health ${ }^{(12)}$; changes to the national curriculum guidelines for undergraduate courses in speech-language pathology, which now prioritize country's healthcare system ${ }^{(13)}$; teamwork and attention to comprehensive health and the inclusion of speech-language therapy in services related to the Family Health Strategy ${ }^{(6)}$.

And finally, regarding changes related to the workplace, it is noteworthy that the increase of respondents' activity in regular schools and a reduction of activity in special schools are linked to Brazilian educational policies that state the education of students with special educational needs (PNEEs) must occur in the regular school system.

Actions aimed at specialized educational services that are able to promote the inclusion of PNEEs in mainstream education should be implemented by multidisciplinary teams composed of professionals in education and health, including speech-language pathologists ${ }^{(14)}$.

Considering that education is a basic right ${ }^{(15)}$, it is understood that the role of the speech-language therapist should aim to improve the quality of education at all levels ${ }^{(14)}$.

This study conducted an analysis of the professional profile of only two Brazilian states, including about $10 \%$ of all speech-language therapists in Brazil. We emphasize the need for the development of such studies at a national and/ or regional level in order to ascertain the profiles that characterize the social role of speech-language pathology.

\section{CONCLUSION}

This study showed a change in the profile of speech-language therapists working in the states of Paraná and Santa Catarina in 2000 and 2011, which could be seen in the shift primarily from clinical and rehabilitative actions in private institutions to actions aimed at prevention and promotion in public health and educational institutions. This shift points to the need to improve academic and professional training for speech-language pathologists, with a focus on the dissemination of knowledge and practices to support the systematization of interventions aligned with the guidelines and policies for public health services and education.

\section{REFERENCES}

1. Ferreira LP, Russo ICP, Adami FF. Fonoaudiólogos doutores no Brasil: perfil da formação no período de 1976 a 2008. Pró-Fono. 2010;22(2):89-95. http://dx.doi.org/10.1590/S0104-56872010000200004 2. Silva DGM, Sampaio TMM, Bianchini EMG. Percepções do fonoaudiólogo recém-formado quanto a sua formação, intenção profissional e atualização de conhecimentos. Rev Soc Bras Fonoaudiol. 2010;15(1):1-9. http://dx.doi.org/10.1590/S1516-80342010000100010

3. Behlau M, Gasparini G. Education of speech-language pathologists and audiologist in Brazil. Folia Phoniatr Logop. 2006;58(1):14-22.

4. Costa KN, Guimarães VA. Fonoaudiologia nos serviços de urgência e emergência do Brasil: série histórica de 2005 a 2011. Distúrb Comum. 2012;24(1):69-75.

5. Guimarães VC, Barbosa MA, Porto CC. O perfil da Fonoaudiologia em hospitais universitários brasileiros. Distúrb Comum. 2009;21(2):199206.

6. Andrade AF, Lima MM, Monteiro NP, Silva VL. Avaliação das ações da Fonoaudiologia no NASF da cidade do Recife. Audiol Commun Res. 2014;19(1):52-60. http://dx.doi.org/10.1590/S2317-64312014000100010 7. Ferreira CL, Silva FR, Martins-Reis VO, Friche AAL, Santos JN. Distribuição dos fonoaudiólogos na atenção à saúde no estado de Minas Gerais entre 2005 e 2010. Rev CEFAC. 2013;15(3):672-80. http://dx.doi. org/10.1590/S1516-18462013005000011

8. American Speech-Language-Hearing Association. Highlights and trends: ASHA counts for year end 2009 [acesso em: 24 mar 2014]. Disponível em: http://www.asha.org/uploadedFiles/2009-Member-Counts. pdf

9. Banco Mundial. Envelhecendo em um Brasil mais velho. Washington, DC: Banco Mundial; 2011 [acesso em: 20 maio 2014]. Disponível em: http://www.siteresources.worldbank.org

10. Marino VCC, Gimeniz-Paschoal SR, Paura AC, Guida HL, Giacheti CM. Inserção de graduados em fonoaudiologia de uma universidade pública em programas de pós-graduação. Rev CEFAC. 2012;14(1):46-56. http://dx.doi.org/10.1590/S1516-18462011005000110 
11. Freitas CHSM. Dilemas no exercício profissional da Odontologia: a autonomia em questão. Interface (Botucatu). 2007;11(21):25-38. http:// dx.doi.org/10.1590/S1414-32832007000100004

12. Moreira MD, Mota HB. Os caminhos da fonoaudiologia no Sistema Único de Saúde - SUS. Rev CEFAC. 2009;11(3):516-21. http://dx.doi. org/10.1590/S1516-18462009000300021

13. Ceccim RB, Feuerwerker LCM. Mudança na graduação das profissões de saúde sob o eixo da integralidade. Cad Saúde Pública. 2004;20(5):1400-10. http://dx.doi.org/10.1590/S0102311X2004000500036
14. Ramos AS, Alves LM. A fonoaudiologia na relação entre escolas regulares de ensino fundamental e escolas de educação especial no processo de inclusão. Rev Bras Educ Espec. 2008;14(2):235-50. http:// dx.doi.org/10.1590/S1413-65382008000200007

15. Dazzani MVM. A psicologia escolar e a educação inclusiva: uma leitura crítica. Psicol Cienc Prof. 2010;30(2):362-75 http://dx.doi. org/10.1590/S1414-98932010000200011 